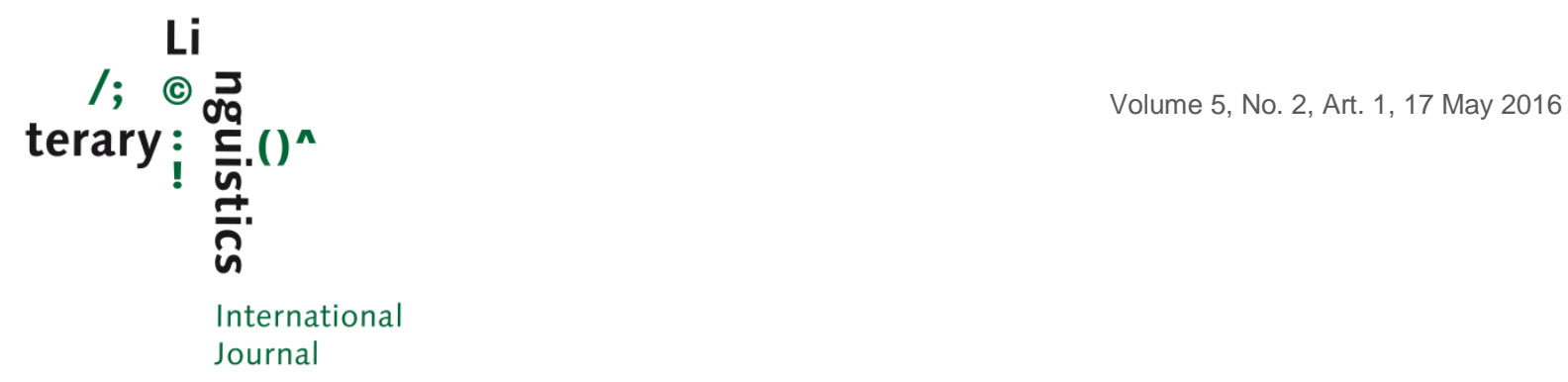

\title{
Introduction: Approaches to Fictional Dialogue
}

\author{
Elise Nykänen and Aino Koivisto, University of Helsinki
}

Keywords:
Direct speech
representation,
unreliable
narration,
hypothetical
speech,
constructed
dialogue,
fictional
dialogue,
conversational
dialogue, auto-
biographical
writing,
fictionality,
linguistic
approaches to
dialogue,
rhetorical
approaches to
dialogue in
narrative

This special issue is devoted to a cross-disciplinary investigation of a specific literary phenomenon, fictional dialogue. By fictional dialogue, we refer to passages of character-character conversation within a literary text. More specifically, our interest lies in fictional dialogue as a narrative mode, and in how this mode is made use of in prose fiction where the narrator frames the dialogue in the narration (as opposed to drama or dialogue novels that are constructed mainly upon characters' speech). The special issue aims to engender an appreciation and a better understanding of the workings of dialogue by drawing on the insights and methods of both literary studies and linguistics. Our starting point and the impetus for this type of cross-disciplinary approach is the following: While fictional dialogue is considered to be an independent narrative mode, it also makes use of the characteristics of everyday conversation. In other words, we claim that while understanding dialogue depends partly on the reader's experiences of real-life conversation and can thus be examined in relation to it, the interpretation of dialogue is, and also should be, determined by the overall design of a literary text and the historically changing conventions, genres, periods, and styles of literary tradition (see also e.g. Thompson 2012; Nykänen \& Koivisto 2013). In our view, fictional dialogue is of special interest in literary-linguistic studies because of this double orientation.

The methodology used in the articles featured here draws from multiple approaches within literary studies and linguistics. These methods include rhetorical-ethical approaches to narrative, cognitive, and "natural" narratology; the study of everyday conversational storytelling; and Conversation Analysis (CA).

These theoretical approaches have brought new insights to the interdisciplinary study of literature that falls under the umbrella term "literary linguistics." Despite our interest in the similarities between "real" and fictional conversation, the articles do not engage in assessing whether dialogues in prose fiction are "good" or "bad," i.e., whether the author has succeeded in producing realisticsounding dialogue or whether he or she has a good "ear" for it (see Thompson 2012: 15). Rather, the articles will examine the ways in which passages of fictional dialogue create and reflect the dynamics between the fictional characters within the storyworld, which is where pragmatic or interactional approaches to real conversation prove their usefulness (see esp. the article by Nykänen \& Koivisto). From a more rhetorical perspective, we are interested in 
how dialogue can be seen as a sympathy-promoting mode that is deployed to engage the reader empathetically and ethically with the characters and the storyworld (see the articles here by Nykänen \& Koivisto, Karttunen, and Mildorf). That is, dialogue in fiction is not only used to depict character-character relationships but also serves other levels of communication in narrative. This Introduction provides some necessary background information for the study of fictional dialogue within different disciplines. We begin by giving an overview on the position, status, and research history of fictional dialogue in the field of (post)classical narratology. We then proceed to introduce stylistic (i.e. more linguistically oriented) approaches that draw on pragmatic models of speech and conversation. Following these overviews, we will say something more about the rhetoric approach - the most important method used in the articles presented here. Finally, we will introduce the three articles and illustrate their relationship to the methods and approaches described.

\section{Fictional dialogue and direct speech representation in narratology}

Dialogue (lat. dialogus $<$ grk. dialogos) is a narrative mode that displays a conversation or speech between two characters or a group of people (polylogue). ${ }^{1}$ In narrative fiction, dialogue is easy to distinguish from the unfolding narration. The direct mode of speech is usually marked by quotation marks, dashes, or other conventional signs that frame the characters' utterances. Conversational exchanges between characters are typically accompanied by speech tags, which identify the speakers. They may either precede or follow the lines of dialogue. Speech tags can also provide the reader with information about the style or tone of the characters' voices, the rhythm of the speech, the actions performed while talking, and possible non-fluencies or silences. Moreover, comments made by the narrator about the situation in which the conversation occurs may help the reader to prepare for the upcoming interaction (Page 1973: 26; Nykänen \& Koivisto 2013: 11, 32). Due to these conventional frames, the reader is prone to perceive the contrast between the speech and the surrounding frame as an indicator of the "directness" and authenticity of the characters' embedded speech.

Compared to naturally occurring conversation (and dialogue in drama), conversational situations in prose fiction are distinctly multilayered. From the perspective of dialogue, it is essential to acknowledge the embedded quality of direct speech representation. In the typologies of classical narratology, the speech act between characters belongs to the "lowest" level of narrative transmission. This level is determined by the narrator's communication to his or her audience, the narratees. Furthermore, the narrator's communication to this audience is framed by the next level of narrative transmission: indirect

\footnotetext{
${ }^{1}$ As explicated at the beginning of this Introduction, this special issue focuses on the forms and functions of dialogue as a narrative mode rather than as a genre. For a more detailed discussion on the philosophical genre of dialogue and its influences on fictional dialogue, see Kinzel \& Mildorf (2012 and 2014) and Nykänen \& Koivisto (2013: 13-16).
} 
communication from the implied author to the implied reader (or, interchangeably, authorial audience), conceived of as constructions of the real author and the real reader situated on the upper level of the narrative hierarchy, as depicted in Table 1.

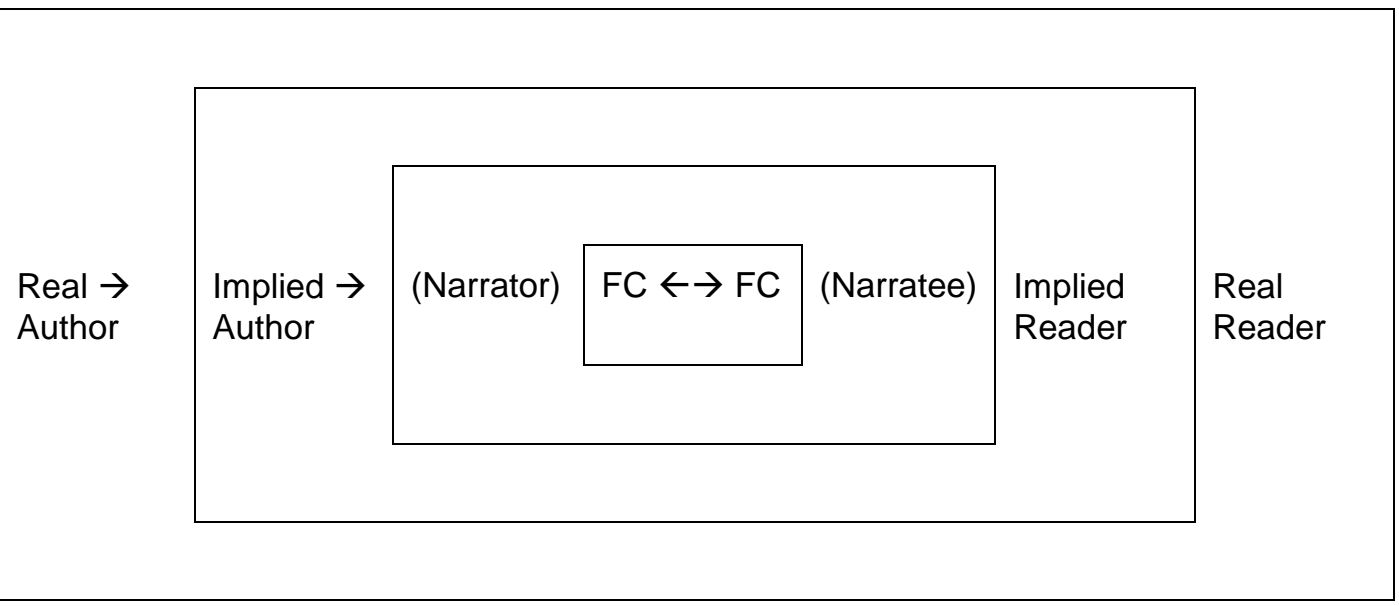

Table 1. The levels of narration according to Rimmon-Kenan (1983: 86) and Phelan (2005: 12). In this model, $\mathrm{FC}=$ fictional character

Even though the representation of speech appears to be "unmediated," there is always the narrator who "quotes" the characters' speech (Rimmon-Kenan 1983: 108). Moreover, since conversations between fictional characters are always more or less framed by the narrator's discourse, the narrator's selective actions determine the course of the storytelling. The narrator decides which "facts" are represented through the characters' speech and which through the narration. While following the characters' dialogues and the narrator's commentary on them, the reader can make inferences about the relationships between the characters and the storyworld they inhabit. In general, the interpretation of dialogue is affected by the overall rhetorical structure of any given narrative text. Dialogue is among the devices that authors use to communicate their ideas, attitudes, beliefs, and values (through the implied author's perspective) to the authorial audience (see "Rhetorical Approaches to Dialogue in Narrative" in this Introduction).

In narrative studies, dialogue has mostly been approached from the perspective of realism and artistic imitation, focusing on the ways in which constructed dialogue resembles real-life conversation (see Thomas 2012: 15). Within this scholarly tradition, fictional dialogue has often been treated as if it were an improvised version of actual conversation (e.g. Kinzel \& Mildorf 2012: 10). Conversational exchanges between characters have been evaluated by examining how effortlessly or reliably an author manages to create an illusion of everyday speech, one that is similar to natural conversations between living and breathing human beings. The "quotations" of characters' speech, mediated by the narrator, have been treated as if they were as identical and non-problematic as the instances of reported speech appearing in real-life contexts - where they are often equally problematic (Fludernik 1993: 409; Karttunen 2010: 243). 
The long tradition of addressing dialogue as if it were a direct linguistic transcription of speech has been seen as resulting from the "speech category approach" established in classical narratology (e.g. Palmer 2004). In structuralist and formalist traditions, the modes of speech and thought representation have been delineated into distinct categories on an axis of diegetic and mimetic discourse. The more diegetic the mode of representation, the more "control" the narrator has over the story, as Table 2 shows.

\begin{tabular}{|c|c|c|c|c|c|}
\hline \multicolumn{5}{|l|}{ Diegesis } & \multirow{2}{*}{$\begin{array}{l}\text { Mimesis } \\
\text { Free indirect } \\
\text { discourse } \\
\text { (First-person } \\
\text { interior } \\
\text { monologue) }\end{array}$} \\
\hline $\begin{array}{l}\text { Diegetic } \\
\text { summary }\end{array}$ & $\begin{array}{l}\text { Indirect } \\
\text { content } \\
\text { paraphrase }\end{array}$ & $\begin{array}{l}\text { Indirect } \\
\text { discourse }\end{array}$ & $\begin{array}{l}\text { Free } \\
\text { indirect } \\
\text { discourse }\end{array}$ & $\begin{array}{l}\text { Direct } \\
\text { discourse } \\
\text { (Monologue, } \\
\text { dialogue) }\end{array}$ & \\
\hline
\end{tabular}

Table 2. The types of speech representation according to Rimmon-Kenan (1983: 109)

In the formal and linguistic typologies of narratology (such as Rimmon-Kenan's model above), critical attention has been given to the various modes of speech and thought, yet the representation of thought has dominated the discussion in narrative studies (Thomas 2012: 1). According to scholars such as Monika Fludernik (1993) and Meir Sternberg (1982), there has been an imbalance between focusing on speech and thought on the one hand, and analyzing the forms and functions of speech and thought representation on the other. Generally speaking, the modes of indirect discourse (free indirect speech in particular) have been an object of continuous critical debate, whereas the dynamics of the direct modes (including fictional dialogue) have been neglected. In addition, while the functions of the indirect modes have been examined extensively, their forms have not been given critical attention (Fludernik 1993; Sternberg 1982). For instance, the study of the functions of empathy and irony in free indirect discourse has led to a neglect of the rhetorical and linguistic strategies through which these effects are generated (Fludernik 1993: 5; see also Palmer 2004: 62-63).

Among the reasons for the existing imbalance in narrative theory, scholars have pointed to the co-emergence of modern narrative theory (influenced by New Criticism and Structuralism) along with the innovations of modernist prose. The modes of representation favored by modernist classics (such as free indirect discourse or the new techniques of interior monologue) moved the focus from fictional speech to the characters' "inner speech." Dialogue, the more "conventional" mode of speech and thought representation, was left on the fringes of academic discussion. Literary innovations that seemed highly "literary" and "aesthetic," such as free indirect discourse, seemed to call for more scholarly attention (Sternberg 1982: 69). Dialogue was considered to be a narrative strategy that was self-evident, unproblematic and therefore in no need of theoretical clarification. This idea has been tentatively reassessed in postclassical narratology. 
In narrative theories of recent decades, certain tendencies have emerged that highlight the "natural," real-life qualities of fictional stories and the role of the reader in applying everyday frames while interpreting these stories. In her groundbreaking study Towards a 'Natural' Narratology (1996), Monika Fludernik presented ideas that have become a guideline for further debates on "natural" storytelling within cognitive narratology. According to her, the primary strategy of reading involves the reader's tendency to interpret the fictional reality through certain cognitive models and scripts, such as "telling," "experiencing," "viewing," and "reflecting" (Fludernik 1996: 43-46; see also Herman 2002: 171). Everything that the reader encounters within the fictional world is, as a rule, artificial and fictional, but at the same time, the readability of the narrative is dependent on the "natural" cognitive frames that the reader applies when reading fiction. In addition to literary models and conventions, the interpretation of fictional dialogue, too, is linked to these real-life models of conversational storytelling and interaction. According to Fludernik, the naturalness of a narrative model stems from the oral, everyday narratives that constitute the prototype of all narratives (Fludernik 1996: 43-46, 57). The cognitive frames of conversational storytelling and interaction serve as the reader's model for making sense of those principles according to which human communication and conversation are shaped in fictional dialogue. Jarmila Mildorf's article in this issue draws on linguistic discussions about conversational storytelling and quotation while exploring the functions of dialogue in autobiography.

The "naturalness" of all narratives has also been extensively criticized, especially among scholars who see narrative fiction as consisting of structures and conventions that are determined by cultural and literary models rather than real-life prototypes (see Alber, Iversen, Nielsen \& Richardson 2010; Alber 2009, Strawson 2004; also Tammi 2006). The most urgent question seems to be to what extent fiction and reading fiction concern the reader's ability to apply reallife cognitive frames and to what degree these frames are linked to the use, manipulation, and parody of previous literary conventions. This question emerges particularly when reading texts that are mainly built on dialogue, or that play with the conventions of writing "realistic" speech. Laura Karttunen's article in this issue addresses fictional dialogue in character narration in which the characters' speech reported by the first person narrator is not necessarily reliable, even though presented in the form of a dialogue. That is, the accuracy and reliability of the characters' reported speech cannot be deduced from its linguistic form.

Recently, there has been a growing urge to examine the dynamics and characteristics of dialogue as a specific mode of representation. The earlier, pioneering work on speech representation in fiction (Page 1988, Chapman 1984 , Leech \& Short 1981) has been followed by more recent studies in which the new methodologies of cognitive linguistics, Conversation Analysis, and postclassical narratology have been adapted for the study of fictional dialogue (Thomas 2012, Kinzel \& Mildorf et al. 2012 and 2014, Koivisto \& Nykänen et al. 2013, also Karttunen 2010). These studies emphasise that fictional dialogue is a key narrative device whose intrinsic problems and strategies are shaped by both the larger contexts of fictional works and literary-historical traditions. This 
special issue elaborates on the insights of this "new wave" of interest in dialogue. Our double focus on fictional dialogue both as an independent narrative mode and as a literary device that makes use of the characteristics of everyday conversation seeks to overcome the biases of the above-introduced approaches to speech representation. Analyzing dialogue, not only from the perspective of realism or in the context of other modes of speech (and thought) representation, widens the scope of exploring the specific functions of dialogue in fictional texts. The articles in this issue, then, focus on the contextual, pragmatic, and rhetorical analysis of direct speech representation. In the discussion that follows, we will examine the relevance of linguistic approaches in analyzing fictional dialogue.

\section{Linguistic approaches to dialogue}

For a linguist interested in everyday language use and conversation, fictional dialogue offers an interesting point of comparison. To what extent is artificial, fictional conversation true to the norms and conventions of everyday talk, and what are the linguistic means for achieving the effect of a realistic conversation? Furthermore, to what extent can we apply linguistic methods to better understand the workings of fictional dialogue? In this section, we offer a brief overview of how linguists and stylisticians have attempted to explore fictional dialogue.

In the field of stylistics, different pragmatic models and approaches have been applied to the study of fictional dialogue. These include, but are not limited to, speech act theory, politeness theory, Grice's Maxims, Discourse Analysis, and Conversation Analysis. Linguistic methods are typically employed eclectically, combining aspects of different approaches (see e.g. Toolan 1985). The general justification for the application of linguistic models is that, on the surface level, there are many resemblances between real and fictional conversation. The most visible is perhaps turn-taking (see Sacks, Schegloff \& Jefferson 1974): the participants in real conversation as well as in fictional dialogue take turns when talking to one another; stylisticians have, for example, been interested in the power relations reflected in such turn-taking dynamics (see Leech \& Short 2007 [1981]: 244, Toolan 1987: 396-397 and Thomas 2007: 85-86). In drama, the speakers take turns without the narrator visibly interfering through speech tags or other types of commentary, which has made drama a popular object of study within stylistics (see e.g. Burton 1980, Herman 1995; Piazza 1999, Short 1989, Ivanchenko 2007, Mandala 2007, Bowles 2009). Dialogue in prose fiction, which is the focus of this special issue, has attracted somewhat less interest among stylisticians (however, see e.g. Leech \& Short 2007 [1981], Toolan 1987, Coleman 2000, Thomas 1997, 2002). In analyzing dialogue in prose fiction, it is essential to consider the role of the narrator as the mediator of dialogue. This means that there is another level of communication compared to drama (narrator-audience). If the role of the narrator is neglected, the danger is, as Thomas (2002: 661) puts is, "that the dialogue is approached as naturalistic and the complexities of the interface between the dialogue and the framing work of the narrator are overlooked." 
In the interpretation of fictional dialogue, the central assumption among stylisticians is that dialogue makes use of the norms and conventions of everyday talk as resources for meaning-making. To quote Toolan (1985: 193), "crucial structural and functional principles and patterns are at work in fictional dialogue as they are in natural conversation." Several stylisticians also point out that understanding fictional conversation and turns-at-talk by the characters is similar to the interpretative process that takes place when engaging in real conversation: we do not interpret words and clauses but rather intentions and actions (Leech \& Short 2007 [1981]: 231-232, Toolan 1990: 276-277). Stylisticians argue that we need pragmatic interpretative strategies in order to understand what the co-participant is doing with his or her turns in both contexts. In the context of fiction, this does not only concern interactions between characters within the storyworld, but is also reflected in interactions between the literary text and the reader. This means that the reader, as well as relying on the explicit commentary by the narrator, judges characters, their relationships, and the situation they are in, on the basis of their dialogue (Leech \& Short 2007 [1981]: 242-245, Ivanchenko 2007: 87).

Stylisticians have also attempted to show exactly how fictional dialogue differs from natural conversation. For example, it has often been pointed out that written dialogue exhibits a restricted set of resources for indicating the way the turns-at-talk are uttered, since no paralinguistic resources, such as intonation, rhythm, or emphasis can be employed. Lacking these, fictional dialogue may resort to typographical resources and commentary provided by the narrator. Furthermore, fictional dialogue has been regarded as a stylized or "tidied-up" version of talk (see e.g. Fludernik 2005: 559). Typically, dialogue does not entail "features of normal non-fluency," such as hesitation pauses, false starts, overlapping talk, and repair that are characteristic of natural conversation and to some extent overlooked by people when conversing (see e.g. Leech \& Short 2007 [1981]: 129-134, Toolan 1990: 275, Thomas 2012: 23). According to Leech and Short, when these types of features are represented in dialogue, they need to be considered as serving a "communicative purpose." For example, nonfluency may be used as a way of depicting a character's state of mind, such as nervousness or feeling awkward in a social situation (Leech \& Short 2007 [1981]: 133). This is of course true of everyday conversation as well, but in fiction we need to consider these features as intentionally used means of characterization.

In stylistics, there are differences between the various "branches" of the field in terms of how fictional dialogue should be approached and what the underlying assumptions or guiding principles are. Discourse stylistics, which has its origins in discourse analysis (DA), assumes that literary dialogue is just one type of discourse among others: "discourse stylistics views literary texts as instances of naturally occurring language use in a social context" (Hall \& Simpson 2002: 136; see e.g. Burton 1980 for an early and influential example of DA applied to drama dialogue). From our perspective, the problem with this approach lies in this very premise: even though it is useful to see similarities between fictional dialogue and other types of discourse, it is problematic to treat fictional conversation in the same way as any other language data (see also Thomas 
2012: 27 for a critique). Thus the danger is that the role and functions of dialogue within the literary work are neglected. This DA-influenced stylistics differs from a more literary-oriented stylistics that holds that "fictional dialogue is an artificial version of talk, partly shaped by a variety of aesthetic and thematic intentions and conventions" (Toolan 1985: 193, 1990: 275). Such is the view advocated in this special issue as well, as already pointed out: while fictional dialogue draws on the resources of natural conversation, its interpretation is heavily dependent on the context of the literary work, the guiding role of the narrator as well as the historically changing literary conventions and ideals (see also Nykänen \& Koivisto 2013 and, for a similar approach, Thomas 2002, 2012, and Ivanchenko 2007). In line with Thomas (2012: 18), we also see the reader's role as essential in "participating in bringing scenes of dialogue to life."

In our view, the method of Conversation Analysis, which is compatible with modern narratological approaches, seems particularly suitable for a detailed, interactionally oriented analysis of fictional dialogue (see also Ivanchenko (2007) and Bowles (2009) who use CA to analyze drama). CA offers tools for analyzing the moment-by-moment unfolding of interaction between the participants in natural conversations (see e.g. Heritage 1984; Sidnell \& Stivers 2013, for introductions to the method). CA-influenced readings of dialogue focus on the details of individual turns (i.e. turn design) and on the conversational actions they accomplish, but also, and perhaps more importantly, on the sequences of turns and social activities within them. This type of approach is taken in Nykänen \& Koivisto's article on Rosa Liksom's short stories (see also articles in Koivisto \& Nykänen (eds.) (2013)). The authors address the ways in which the emerging disagreements and discrepancies of perspectives between Liksom's characters are reflected in the dynamics of the dialogues - for example, how the characters oppose or ignore each other's turns and also where and when silences are reported. The multimodal aspects of interaction are another important aspect of fictional dialogue that can be analyzed from a CA perspective. In fiction, gestures, tones of voice and facial expressions are mainly depicted in the speech tags and in other commentary provided by the narrator (see also Thomas 2007: 83). However, these aspects should not be seen as "natural" components of the interaction between characters, but rather as the narrator's device for depicting the characters' non-verbal behavior and emotional states.

The articles in this special issue endeavor to employ these various linguistic approaches and to reflect upon the similarities between fictional dialogue and its real-world language use. However, the collection's ultimate aim is to analyze the role and meaning of dialogue within a literary work as well as in relation to its overall topic and import. Next, we take up rhetorical approaches to narrative, through which it will be possible to examine fictional dialogue and direct speech representation in the context of narrative communication on a more general level. Rhetorical approaches to narrative offer tools for analyzing the larger contexts of narrative transmission and the ways in which these communication structures are related to the characters' discourse and interaction at the level of storyworlds. Rhetorical analysis also provides a means to explore the cognitive, ethical, and affective dimensions of stories. 


\section{Rhetorical approaches to dialogue in narrative}

As a narrative device, fictional dialogue is among the textual strategies used to engage an audience cognitively, ethically, and emotionally with a narrative. All articles in this issue illustrate our view that fictional dialogue is determined by the whole design of a text. Conversations between characters are very much determined by the author's aesthetic purposes in building fictional interaction in order to trigger certain cognitive, emotional, and ethical responses in the authorial audience. Rhetorical approaches to narrative have sought to define the various concepts, models, and methods used to analyze the layered communication in narrative texts. This means that texts have not only been analyzed on the level of linguistic patterns, but also on the level of the literary works' overall structure, and in the context of their ethical dimensions.

In rhetorical approaches to fiction, narrative is seen as "an interaction between an author and an audience through the medium of a text for some purpose" (Phelan 2005b: 500). Among the first influential theories from the perspective of the study of narrative rhetoric is Mikhail Bakhtin's dialogism, which tackles the ideological dimensions of literature (ibid.). According to Bakhtin, fictional dialogue is one of the most concrete elements of dialogism. However, the principle of dialogism manifests itself also on a more general level, serving as a general law of human consciousness, culture, and the use of language.

Even though Bakhtin's theory of dialogism has been highly influential, the later work of Chicago School criticism, and the studies following it, have established models and tools for rhetorical analysis which have been adopted by many scholars since. The Chicago School's rhetorical critics moved the focus of study from a novel's dialogism (or double-voiced discourse) to the ethics and ideology of narrative in general. Also, the influences of a narrative's ideological and ethical dimensions on the reader's understanding of narrative communication were among their interests (Phelan 2005b: 501). The most influential figure in the second phase of rhetorical study was Wayne C. Booth, whose impact on narrative studies has been enormous. Booth's The Rhetoric of Fiction (1961) introduced such frequently debated terms as "implied author" and "unreliable narration," which are also utilized in this issue's articles to analyze the dynamics of narrative transmission as related to the strategies of dialogue. Narratives are seen as authors' designs that affect the audience's emotions and desires by way of making technical choices, such as providing or withholding overt narrative commentary. Booth's ideas have been elaborated on in the third wave of rhetorical study by scholars such as Peter Rabinowitz (1987) and James Phelan (1996, 2005a). In particular, Phelan's theory of character narration, including his discussion on the rhetorical dynamics and ethical dimensions of character narration, has affected recent developments in the study of narrative rhetoric (see the articles by Karttunen; and Nykänen \& Koivisto, in this issue).

From the rhetorical perspective, fictional dialogue needs to be understood as one of the narrative devices through which the (implied) author communicates his or her perspective of the fictional world to the authorial audience (see the model of narrative communication presented earlier in this Introduction). There 
is a fundamental difference between the omniscient third person narrator, who is not involved in the narrated events in any way, and a first person character narrator, who is telling the story from his or her perspective. The indirect discourse of an omniscient narrator, for instance, may provide a more accurate version of the "original" speech and events than the direct discourse of an unreliable first person narrator (Sternberg 1982: 142). As the case studies of Karttunen and Mildorf in this issue show, a relevant aspect in determining the reliability of the passages of direct speech is the role of the narrator, both in fiction and in the genre of autobiography.

The interpretation of fictional dialogue is determined not only by the choice of the narrator type, but also by the context and the functions of the characters' interaction in the larger framework of a storyworld's overall structure, its thematics, and the aesthetic design of a literary text. Phelan (2005a) introduces a typology of three different components of narrative that are also relevant to the analysis of fictional dialogue. These components are the mimetic, thematic, and synthetic aspects of storytelling, each affecting the audience's responses. Responses to the mimetic component of dialogue involve an interest in the characters as possible, imaginary people interacting and communicating with each other within a storyworld, like people in the real world. Responses to the thematic component involve speech representation in the context of the cultural, ideological, philosophical, or ethical issues being addressed by the characters in their speech or by the implied author through indirect narrative communication. Responses to the synthetic component involve the audience's interest in both the characters' interaction and the larger narrative as an artificial construct. The synthetic qualities of dialogue may be more or less emphasized (see Phelan 2005a: 20). The representation of speech may tend toward realism, but equally toward artifice, depending on the genre, style, and literary period to which the narrative belongs.

As we have shown in this Introduction, the mimetic approach has been the most prominent way of reading fictional dialogue. In this issue, our aim is to continue to build a more holistic perspective on dialogue, taking into account not only the mimetic but also thematic and synthetic components of storytelling. Even though fictional dialogue has its mimetic dimensions, the larger narrative as a rhetorically and ethically complex construction of communication often challenges or even transgresses the mimetic boundaries of everyday conversation and storytelling. Nykänen and Koivisto's article proceeds from an analysis of the mimetic aspects of the moment-by-moment unfolding of characters' interaction to an examination of the rhetorical strategies of dialogue at a more thematic level. In Laura Karttunen's and Jarmila Mildorf's articles, linguistic discussions of quotation and conversational storytelling are employed to examine the forms of constructed dialogue and its rhetorical functions. Karttunen analyzes the uses of hypothetical direct speech in expressing and representing emotions and attitudes of a potentially unreliable first-person narrator who retrospectively contemplates and reports on his past. Mildorf's article tackles the uses of constructed dialogue in autobiography in which direct speech representation serves a variety of purposes such as self-performance, ridicule, stereotyping, and creating verisimilitude. 


\section{Introduction to the articles}

In this special issue, apart from the rhetorical approach to dialogue discussed above, the contributors have drawn on different methods and theoretical models from linguistics. In the first two articles, Karttunen and Mildorf see a resemblance between conversational storytelling and the role of dialogue and reported speech in fiction; they also acknowledge that dialogue within character narration and reported speech is not necessarily true to an "original" speech event (whatever that may be), but rather "constructed dialogue" that serves the purposes of the story and the narrative structure. In the third article by Nykänen \& Koivisto, the resemblance between real conversation and fictional dialogue is viewed from the perspective of the dynamics of interaction between fictional characters at the micro level, as inspired by Conversation Analysis.

Laura Karttunen's article discusses the role of dialogue and reported speech events in Kazuo Ishiguro's An Artist of the Floating World. She argues that an analysis of speech reporting has major consequences for the interpretation of Ishiguro's novel, which is not always the case when linguistic theories are applied to literary texts. Drawing from studies on conversational storytelling and hypothetical direct speech, Karttunen shows how the mechanics of direct speech representation are connected to the character narrator Masuji Ono's unreliability. The faithfulness and accuracy of reported speech is challenged in Ishiguro's novel, where dialogue serves two different purposes: first, the unreliable character narrator's reporting of his past to his audience within the storyworld, and secondly, the implied author's communicating to the authorial audience. In addition, Karttunen considers how hypothetical or invented direct speech may serve to reflect the character narrator's past and present emotions - another aspect familiar from what we know about the use of direct reported speech in everyday storytelling.

Jarmila Mildorf analyzes the functions of dialogue in Frank McCourt's autobiography Angela's Ashes. She shows that while autobiography is assumed to be a truthful representation of past events, it is questionable how accurately original speech events can actually be remembered, which is a problem in everyday storytelling as well. Reproduced speech events are then conceived of as constructed dialogues, employed in a way similar to fictional dialogue. In autobiographical writing, dialogues are seen as a shift to a "dramatic mode" through which the author is able to convey an implicit evaluative stance toward other people who engage in dialogue. In other words, the sequences of dialogue become part of rhetorical acts that are intentionally designed by the narrator. As Mildorf herself puts it, "Frank McCourt's specific uses of dialogue may offer us an insight into his own evaluative stance on situations in the past and into how he retrospectively related to other people in his life."

Elise Nykänen and Aino Koivisto then analyze the dynamics of dialogue in three of Rosa Liksom's short stories that are constructed almost entirely of dialogue, with minimal involvement on the part of the narrator. Nykänen and Koivisto adopt two different approaches to dialogue. First they analyze dialogue from the micro level, as interaction between the characters within the storyworlds and 
then from a more holistic perspective, paying attention to how dialogue contributes to the rhetorical structure and ethical interpretation of the stories. The article later focuses on the communication between the implied author and the authorial audience. The authors show that resorting mainly to dialogue as a narrative mode works as a way of depicting tensions between the characters, and between them and the surrounding fictional world. This, in turn, engages the reader in an interpretative process of understanding the story's logic both within the fictional world, and at the level of communication between the implied author and the authorial audience.

\section{References}

Alber, Jan (2009). Impossible Storyworlds - And What to Do with Them. Storyworlds, $1(1), 79-96$.

Alber, Jan, Iversen, Stefan, Skov Nielsen, Henrik \& Richardson, Brian (2010). Unnatural Narratives, Unnatural Narratology: Beyond Mimetic Models. Narrative, 18, 113-136.

Bakhtin, Mikhail (1981). The Dialogic Imagination: Four Essays. Voprosy literatury I estetiki, ed. Michael Holquist, trans. Caryl Emerson \& Michael Holquist. Austin: University of Texas Press.

Bonheim, Helmut (1982). Narrative Modes: Techniques of the Short Story. Cambridge: D.S. Brewer.

Booth, Wayne C. (1983 [1961]). The Rhetoric of Fiction. Chicago: University of Chicago Press.

Burton, Deidre (1980). Dialogue and Discourse. A Sociolinguistic Approach to Modern Dialogue and Naturally Occurring Conversation. London: Routledge and Kegan Paul.

Chatman, Seymour (1978). Story and Discourse: Narrative Structure in Fiction and Film. Ithaca and London: Cornell University Press.

Coleman, Dan (2000). Tuning in to Conversation in the Novel: Gatsby and Dynamics of Dialogue. Style, 34(1), 52-77.

Fludernik, Monika (1993). The Fictions of Language and the Languages of Fiction: The Linguistic Representation of Speech and Consciousness. London and New York: Routledge.

--- (1996). Towards a 'Natural' Narratology. London and New York: Routledge.

--- (2005). Speech Representation. Routledge Encyclopedia of Narrative Theory, eds. David Herman, Manfred Jahn, \& Marie-Laure Ryan. London: Routledge, 558-563.

Genette, Gérard (1980). Narrative Discourse: An Essay on Method, trans. Jane E. Lewin. Ithaca: Cornell University Press.

Heritage, John (1984). Garfinkel and Ethnometodology. Cambridge: Polity Press.

Herman, David (2002). Story Logic: Problems and Possibilities of Narrative. Lincoln and London: University of Nebraska Press.

--- (2006). Dialogue in a Discourse Context. Narrative Inquiry, 16(1), 75-84. 
Herman, Vimala (1995). Dramatic Discourse: Dialogue as Interaction in Plays. London: Routledge.

Ivanchenko, Andriy (2007). An 'Interactive' Approach to Interpreting Overlapping Dialogue in Caryl Churchill's Top Girls (Act 1). Language and Literature, 16(1), 7489.

Karttunen, Laura (2010). Hypoteettinen puhe ja suoran esityksen illuusio (Hypothetical Speech and the Illusion of Direct Discourse). Luonnolliset ja luonnottomat kertomukset. Jälkiklassisen narratologian suuntauksia (Natural and Unnatural Narratives. Approaches in Post-Classical Narratology), eds. Mari Hatavara, Markku Lehtimäki \& Pekka Tammi. Helsinki: Gaudeamus, 220-252.

Kinzel, Till \& Mildorf, Jarmila (2012). New Perspectives on Imaginary Dialogues: An Interdisciplinary Dialogue. Imaginary Dialogues in English: Explorations in a Literary Form, eds. Till Kinzel \& Jarmila Mildorf. Heidelberg: Universitätsverlag Winter, 9-30.

Kinzel, Till \& Mildorf, Jarmila, eds. (2014). Imaginary Dialogues in American Literature and Philosophy: Beyond the Mainstream. Heidelberg: Universitätsverlag Winter.

Koivisto, Aino \& Nykänen, Elise, eds. (2013). Dialogi kaunokirjallisuudessa (Dialogue in Fiction). Helsinki: Finnish Literature Society.

Nykänen, Elise \& Koivisto, Aino (2013). Näkökulmia kaunokirjalliseen dialogiin (Perspectives on Fictional Dialogue). Dialogi kaunokirjallisuudessa (Dialogue in Fiction), eds. Aino Koivisto and Elise Nykänen. Helsinki: Finnish Literature Society, 9-56.

Leech, Geoffrey N. \& Short, Michael H. (2007 [1981]). Style in Fiction: A Linguistic Introduction to English Fictional Prose. London: Longman.

Lubbock, Percy (1957). The Craft of Fiction. London: Cape.

Mandala, Susan (2007). Twentieth-Century Drama Dialogue As Ordinary Talk: Speaking Between the Lines. Bodmin: Ashgate Publishing.

Page, Norman (1973). Speech in the English Novel. London: Longman.

Palmer, Alan (2004). Fictional Minds. Lincoln and London: University of Nebraska Press.

Phelan, James (1996). Narrative as Rhetoric: Technique, Audience, Ethics, Ideology. Columbus: Ohio State University Press.

--- (2005a). Living to Tell about It: A Rhetoric and Ethics of Character Narration. Ithaca and London: Cornell University Press.

--- (2005b). Rhetorical Approaches to Narrative. Routledge Encyclopedia of Narrative Theory, eds. David Herman, Manfred Jahn \& Marie-Laure Ryan. London: Routledge, 500.504 .

Piazza, Roberta (1999). Dramatic Discourse Approached from a Conversational Analytic Perspective: Catharine Hayes's Skirmishes and Other Contemporary Plays. Journal of Pragmatics, 31, 1001-1023.

Rabinowitz, Peter (1998[1987]). Before reading: Narrative Conventions and the Politics of Interpretation. Columbus: Ohio State University Press.

Rimmon-Kenan, Shlomith (1983). Narrative Fiction; Contemporary Poetics. London and New York: Methuen. 
Sacks, Harvey, Schegloff, Emanuel \& Jefferson, Gail (1974). A Simplest Systematics for the Organization of Turn-Taking for Conversation. Language, 50, 696-735.

Semino, Elena, Short, Mick \& Wynne, Martin (1999). Hypothetical Words and Thoughts in Contemporary British Narratives. Narrative, 7(3), 307-334.

Short, Mick (1989). Discourse Analysis and the Analysis of Drama. Language, Discourse, and Literature: An Introductory Reader in Discourse Stylistics, eds. Ronald Carter \& Paul Simpson. London: Unwin Hyman.

Sidnell, Jack \& Stivers, Tanya, eds. (2013). Handbook of Conversation Analysis. WileyBlackwell.

Simpson, Paul \& Hall, Geoff (2002). Discourse Analysis and Stylistics. Annual Review of Applied Linguistics, 22, 136-149.

Strawson, Galen (2004). Against Narrativity. Ratio XVII, December, 428-452.

Tammi, Pekka (2006). Against Narrative. (“A Boring Story”). Partial Answers 4(2), 19-40.

Thomas, Bronwen (1997). 'It's Good to Talk'? An Analysis of a Telephone Conversation from Evelyn Waugh's Vile Bodies. Language and Literature, 6(2), 105-119.

--- (2002). Multiparty Talk in the Novel: the Distribution of Tea and Talk in a Scene from Evelyn Waugh's Black Mischief. Poetics Today, 23(4), 657-684.

--- (2007). Dialogue. The Cambridge Companion to Narrative, ed. David Herman. Cambridge: Cambridge University Press, 80-93.

--- (2012). Fictional Dialogue: Speech and Conversation in the Modern and Postmodern Novel. Lincoln and London: University of Nebraska Press.

Toolan, Michael (1985). Analyzing Fictional Dialogue. Language and Communication, 5(3), 193-206.

--- (1987). Analysing Conversation in Fiction: The Christmas Dinner Scene in Joyce's: "Portrait of the Artist as a Young Man." Poetics Today, 8(2), 393-416.

--- (1990). The Stylistics of Fiction: A Literary-Linguistic Approach. London and New York: Routledge. 